\title{
The Relationship Between Learning Style And Student Achievement In History Subject
}

\author{
Ahmad Syakirin Johari ${ }^{1}$, Anuar Ahmad ${ }^{2}$ \\ ${ }^{\text {I }}$ Faculty of Education, National University of Malaysia) \\ ${ }^{2}$ (Faculty of Education, National University of Malaysia)
}

\begin{abstract}
This study aims to look at the relationship between learning styles and attitudes and achievements of students in the subjects of history in Pasir Puteh, Kelantan. The study sample consisted of 244 students of a total of 96 male students and 147 female students which involved five schools in Pasir Puteh, Kelantan. This study used a questionnaire survey method. This study uses a model of learning styles introduced by Selmes (1987). Complete data were analyzed using descriptive and inferential statistical methods. Statistical methods that are being used are frequency, percentage, standard deviation and the mean of the distribution profile, learning styles, and student achievement. While statistical inference used was t-test and Pearson correlation. The findings show that learning styles tend to be practiced by the student is learning style persistent efforts, encouragement, and deep. The results of the t-test showed that there was no significant difference between students' learning styles by gender. In addition, the correlation test results also showed that there was no significant relationship between students' learning styles to student achievement. The implications of this study showed that the students should know the types of learning styles as appropriate to themselves to be used while studying. Teachers also need to adopt appropriate teaching style with students' learning styles and know to attract student interest in exploring the subject taught.
\end{abstract}

Keywords - learning styles, education, history subject, student attitudes and student achievement

\section{INTRODUCTION}

The subject of history is the subjects that discuss the basic humanitarian and social sciences which have long been taught in schools in Malaysia. History subjects considered important in shaping youth minds to understand and accept the differences in attitudes, cultures, and beliefs of each ethnicity in Malaysia. The step in compulsory pass of the history subject in the Malaysian Certificate of Education (SPM), which began in 2013, is a wise step the Ministry of Education (MOE) in order to uphold the science of history. However, the desire need a new paradigm shift in terms of teaching and learning that is appropriate to the demands of the times to meet the challenges and progress of the 21st century. History should be developed and taught with more efficient and attractive and customize with the advancement of information technology nowadays.

Most students have the impression that the subjects of history are a boring subject, unattractive, useless, and no benefit to them. This initial thought would cause the student less focused and less motivated to learn the subjects of history. According to Anuar Ahmad et al (2009) [1], the subjects of history are less interesting by the students and the students assumed that history is a boring subject. The study by Abdul Razak Ahmad \& Abdullah Mohd Noor (2000) [2] in the district of the Petaling Jaya and Kuala Selangor found that students consider the subject of history as a subject that is not giving benefit to them. In addition, if the teacher emphasizes the training of teaching students to think, it can give negative responses from students and it can be eliminated if the teacher thinks creative and innovative, able to carry out the teaching and learning process effectively and able to provide opportunities for students to interact with fellow students and generate excitement in the classroom.

Each student has a different learning style that is not similar to each other and has their own impulse in the learning process in the classroom or outside of the classroom according to Zubaidah Begam (2007) [3] Different learning styles among students are problems that must be faced by teachers so that they can adjust their teaching technique to the students learning style. At the school level students have been separated by their flow and ability of students in class, if the teachers teaching technique befitting with the students learning styles then it will have a positive impact on the understanding and performance as well as captivating their interest to learn more about a certain subject especially History. On the other hand when the teachers teaching techniques unfit with the students learning style, it will impact negatively on the understanding, interest, and students achievements. This proves that learning styles are related to one's own interest, attitude and achievement in the subject that they are studying according to Rosita Binti Ishak (2012) [4]. 
According to Hasmah Binti Iberahin (2014) [5] and Bahrin Abu (2000) [6], the cause of the declining of student academic is that they cannot adapt their learning styles with the teachers teaching technique and does not have the correct learning style. A student should know the types of learning styles that are befitting to them to put into practice in their learning process. Mohd. Mahzan Awang et al [7] states that most students learn the learning techniques and skills by chance rather than planned. This event happened because the students were not disclosed with a specific guidance to carry out their studies. This shows that the education system in Malaysia is not highlighting an organized teaching techniques and learning styles to students according to Rosita Binti Ishak (2012) [4]. If a student is able to recognize what their strengths and weaknesses is, he will become a great and successful person as he is able to know himself (Awang Abdullah, 2011) [8].

Consequently, researchers have used the Model of Learning Styles that have been introduced by Selmes, L.P. (1987) [9], which includes five elements of learning styles that were introduced by him, motivational learning styles, organized learning styles, surface learning styles, deep learning styles, and hardworking learning styles, seem fit to carry out research on learning styles of the subject of History for form four students in Malaysia. The objective of this study was to identify preferred learning styles which often practiced by students and its relationship with attitude and achievement in the subjects of history. This study also wanted to find out the factors those affecting students' learning styles. Thus the process of teaching and learning should be implemented effectively so that students can be formed properly and have the enthusiasm to fathom a subject hence increasing his academic achievement. The results of this study will also give a significant importance to certain parties, especially to students, history teachers, school authorities, and the Ministry of Education (MOE) in providing guidelines for designing appropriate strategies which take into account the learning styles of history in order to help students in improving their academic achievement.

\section{LITERATURE REVIEW}

Learning styles in general can be defined as the force used by an individual to learn. Generally, learning style is the way an individual's learn a lesson by his own impulse (Noorhasliza Binti Mohd Nordin , 2015) [10]. Each student has a learning style that differs from each other. Differences learning style of each student can be measured in terms of self-concept, strength, physical, emotion, and the way of accepting and also information processing that depends on student's capability. Learning style is the way a person's practice of learning and every student has a different way of learning styles and may be changed by experience and surroundings. Based on a study carried out by Orhun, N. (2007) [11], learning style has been defined asthe way of a learner collecting and processing information. According to him again, learning style also is the ideal development, problem solving, and the interest of a student (Noorhasliza Binti Mohd Nordin, 2015) [10].

A learning style refers method or how one learns, receive information, process information, and develop the information learned. Understanding learning styles is very important for a student to give strength and motivation for their success in academics. Although students practice varying learning styles, but the important art is the output or result obtained after the learning process. To ensure a quality learning process for students in the classroom, teachers should play a role to their teaching methods to the students learning styles. Teaching methods and learning styles should be complement to make the learning process a quality, effective, objective achieving, and can attract students to learn more about a studies Baharom Mohammad \& Ilyas Hashim. (2010) [12].

Based on Selmes, L.P. (1987) [9] past studies comprehend that the learning style of each student are different from each other, teachers should play an important role and are wise in adjusting their teaching method with the students learning styles to attract students interests in a particular subject, in a study that was conducted by Dunn , R. (1980) [13] in (Noorhasliza Binti Mohd Nordin, 2015) [10] stated that the outcomes of a learning process can be maximized id the teacher teaching method befit with the students learning style. This is in line with the opinion of Oxford R.L. et al (1991) [14] the compatibility of the teaching method and learning styles can enhance the student achievement to improve their behavior and attitude in academics. A teacher skill in the students learning styles allows him to make preparations and selecting a correct teaching method with the students learning styles (Noorhasliza Binti Mohd Nordin, 2015), [10].

Battroff, S.M. (1993) [15] states that the appropriate learning style is an important factor in determine the success of a student. Students need to be aware of what kind of learning style that is appropriate for them to be adopted by them in order to gained great achievements in the field of education Baharom Mohammad \& Ilyas Hashim. 2010 [12], Robiah Sidin. (2000) [16] . For students who do not know what learning style that suits them, the students will give up and lose interest in studying a subject of study. Therefore, a student's learning style appropriate to the practice itself will get great achievements in the field of studies.

There are several studies that have been conducted by many researchers' related prior learning styles either within or outside the country. The study conducted by Tan Lay Guat. (2006). [17], he conducted studies of students who take the subject of chemistry. Researchers use Selmen model (Selmes, L.P ,1987) [9] to conduct research. The findings of the study found that learning styles tend to be practiced by the students in the 
study is the encouragement of learning styles and learning styles of the surface, followed by a deep learning style. For those who are not fond of learning styles practiced by the students in the study of learning styles and learning styles persistent planned order.

Chua Long Chee. (2002) [18] had conducted a study toward trainee teachers based on gender, race, and the field of study with the following model (Selmes, L.P. ,1987) [9]. The findings found that all trainee teachers who participated in the study practiced a variety of learning styles and are not tied to a particular learning style only. However, teachers are more likely to practice learning styles impulse followed by surface learning styles, learning styles deep, persistent effort of learning styles and learning styles planned. The results obtained by Rahayu Bin Johari (2008) [19] from his study found a boost learning style and the style of the highest planned learning tend practiced by students in the study and followed with profound learning styles, learning styles surface, as well as learning styles tireless efforts got minimum results. This study is consistent with a study conducted by Ang Foo Mei (2006) [20] who found the encouragement of learning styles that tend practiced by students in his study.

Lee, J.K. (2002) [21] conducted a study to identify students' learning styles and their relationship to the achievement by gender and socio-economic development in chemistry. In his study he used Kolb learning style model. Results found that the student achievement in chemistry have a negative correlation with the learning styles of Abstract Conceptualization, but there is a positive relationship between achievement in chemistry learning style.

Briggs has been carrying out research on troubled students in academic learning and achievement in mathematical subjects. In his research he has used Dunn and Dunn learning style model, and the purpose of study is to look at learning styles that match will show improved performance High temperatures in mathematics compared to students who were not pursued learning style match. The findings showed no significant differences in mathematics achievement between the two groups of students.

Studies conducted by Yi Chien Lu. (2007) [22] found that female students practiced learning style better than male students in subjects such as English. This study was also supported by a study commence by $\mathrm{Gu}$ which conducted a study towards the Chinese students in learning English in Singapore. The study found that the learning styles of female students is well-organized than male students in order to master the vocabulary in English. The results of studies that have been carried out by Lee Sui Chin.(2003) [23] related to students' attitudes to subjects of chemistry and knowledge of scientific principles related to the knowledge of students in chemistry, find that students' attitudes to chemical subjects is positive and achievements are at the stage that simple. This study shows there is a distinction which contributed significantly to the students' attitudes to learning interests and social implications for chemical subjects among a collection of students who have a high knowledge of the principles of science, average, and below average. In addition, the research also showed no significant distinction for students' attitudes to enjoyment in learning chemical and views of the chemistry teacher.

\section{OBJECTIVES}

i. Determine the types of learning styles tend to be practiced by the students in the subjects of history.

ii. Identify the different learning styles of students in the subjects of history by gender.

iii. Identify the relationship of learning styles of students in the subjects of history and achievement.

\section{RESEARCH METHODOLOGY}

In this study the researchers used quantitative research survey method to complete the study. Survey study chosen by the researcher is compatible with the length of time researchers in preparing this study. The method is also applicable to the title of the study which the researchers looked at the relationship between learning styles and student attitude and achievement of its four levels. Data that is administered using a questionnaire can helped to determine the trend of learning styles that often practiced by students of history and its relationship with attitude and student achievement in the study based on research by Rosita Binti Ishak. 2012 [4].

The instrument used for this study is a questionnaire consisting of three parts, namely Part A, Part B and Part A division should respect the information respondents, and Part B is related to the five learning styles which are motivation learning styles, planned learning styles, surface learning styles, deep learning styles, and hard work learning styles. There are 25 items that were related to respondents' learning styles and learning styles which each have five items. In Part B are the items were measured using a scale of 1 to 5 likert point. Likert scale of 1 = Strongly Disagree (STS), 2 = Disagree (TS). $3=$ Less Agree (KS), $4=$ Agree (S), and Strongly Agree (SS). Target respondents in this study is the form four student in secondary school in some schools in Pasir Mas, Kelantan. All samples were simple random sampling. A total of 250 questionnaires were distributed to several schools and the number of questionnaires distributed to every school is not the same, but the completed questionnaires that were obtained by the researchers only 244 questionnaires only. 
Descriptive statistical analysis was used to describe the demographic factors of respondents to see the frequency and percentage. For the interpretation of mean and standard deviation are used to seeing this type of learning style often adopted by students. To see more clearly the characteristics of learning styles also use a percentage value. Interpretation of the score mean and standard deviation are used to see the composition of learning styles based on achievement in the subjects of history. The method used is based on the interpretation proposed by Jamil Bin Ahmad (2002) [24], the mean score of 1.00 to 2.33 indicates a low level, the mean score 2.34 to 3.66 indicates a moderate level, and the mean score of 3.67 to 5:00 show low levels. To measure student achievement in the subjects of history, the division made to the achievement of three categories which are high, medium, and low. Students who score between 70-100 percent between are categorized as students get high marks. For students who scored between 50-70 percent are categorized as students get average. While the lessons that scored between 0-49 percent were categorized as students with low achievement.

Inference statistical analysis was also used to examine the relationship or the relationship that exists between two variables, namely the independent variables and the dependent variable. Inferential statistics used in this study is a t-test, one -way and Person correlation. T-test was used to compare the mean between two groups. The tests used by researchers in this study is a t-test independent samples. Significant level used in this study is 0.05 or $5 \%$ ( $\mathrm{p}<0.05)$. The null hypothesis $(\mathrm{Ho})$ used in this study is that there is no significant difference between the mean of the two variables. Comparison min in this study is the mean of the learning styles of gender and flow.

For data analysis using inference is viewing Person correlation test was used to examine the relationship between learning styles and student attitudes and achievement in the subjects of history. Person correlation test was chosen because it coincides with the survey data in the form of a gap (Pallant, 2001; Jackson, 2006). The strength of the relationship between two variables is determined by the correlation coefficient. The correlation coefficient is between -1.00 and +1.00 where the positive sign (+) and negative (-) indicates the level of a relationship. The sign (+) indicates a positive relationship between the sign (-) indicates the existence of a negative relationship researches studied.

\section{FINDINGS AND DISCUSSIONS}

A. Respondents Profile

This study involved 244 respondents of form four students in five schools in Pasir Mas, Kelantan. Table 1 Respondents Profile.

\begin{tabular}{ccccc}
\hline Demography & Variables & Research Sample & Frequency & Percentages (\%) \\
& & & & \\
& \multirow{3}{*}{ Gender } & Male & 96 & 39.3 \\
& & Female & 147 & 60.7 \\
\multirow{3}{*}{ Student } & Stream & Science & 100 & 41.0 \\
& & Art & 144 & 59.0 \\
& \multirow{3}{*}{ Achievement } & & 187 & 76.6 \\
& & High & 37 & 15.2 \\
& & Average & 20 & 8.2 \\
\hline
\end{tabular}

Based on Table 1 shows a total of 244 respondents involved in this study, the results showed that more female students participated in this study. In terms of stream shows that there are more students who take more arts stream differ from the students taking science stream. In terms of student achievement also shows that the academic performance of students receiving higher achievement is higher than the student who gets medium and low achievement. Academic performance of students is assessed through examination Form Three (PT3).

\section{B. The Learning Style tend to Practice by Student}

Table 2: The Learning Style Practiced by students in the subject of History

\begin{tabular}{cccc}
\hline Learning style & Mean & Standard Deviation & Interpretation \\
\hline Encouragement & 3.99 & 0.650 & High \\
Planned & 3.64 & 0.793 & Average \\
Surface & 2.89 & 1.360 & Average \\
Deep & 3.71 & 0.635 & High \\
Persistent efforts & 4.04 & 0.536 & High \\
\hline
\end{tabular}


Table 2 shows that learning style is likely to be practiced by the students ' learning styles persistent effort, followed by a boost learning styles, learning styles depth, followed by a planned learning styles and learning styles of learning is the style most like practiced by students. Of the five 'learning styles are three learning styles that get high score interpretation of learning styles persistent efforts, encouragement, and deep. Whereas planned learning styles and surface retrieve an average interpretation of the score.

This study is consistent with a study conducted by Ong Sze Chong dan Zamri Mahamod. (2014) [25], who found that learning styles tend to be practiced by the students are also learning style persistent efforts, encouragement, and followed with a deep learning style. The findings are similar to a study conducted by Rohazal found that learning style is likely to be practiced by the students' learning styles tireless efforts and deep learning style. However, the study also contradict a study conducted by Tan Lay Guat. (2006). [17] which found that the persistent efforts of learning styles and learning styles depth is less fond of learning styles practiced by the students. However, the encouragement of learning styles is most fond of learning styles practiced by the students. Conflicting results were likely due to differences in subjects with history of chemistry, it shows that the subjects of history favored by students compared with chemistry.

Surface learning style is the simpler and less min interpretation practiced by students in the subjects of history. The findings found that most students' like history subjects and they work very hard to get a brilliant achievement in examinations. This finding contradicts by a study from Ahmad \& Abdullah Mohd Noor (2000) [2] to 240 students in the district of Petaling Jaya and Kuala Selangor that found students consider the subjects of history as a subject side that is not availed.

Each student has a learning style that is not similar to each other and has their own stimulus in the learning process in the classroom or outside the classroom (Mohamed Zakaria ,2007) [26]. A student should know the types of learning styles that are appropriate to them, especially during exams. Students who are not able to identify the learning style that suits them can caused in failed to achieve excellent results in exams and not interested to learn a subject. According to Awang Abdullah (2011) [8], if a student is able to recognize what their strengths and weaknesses, he will become a great and able to be a successful as he is able to know yourself. However, each student practice learning styles vary, but what is more important is the output or result obtained after the learning process is more important for students to actually get good results in examinations.

\section{Learning Styles Differences by Gender}

Table 3 Significant Differences between Learning Styles by Gender

\begin{tabular}{|c|c|c|c|c|c|c|c|c|c|}
\hline Learning Styles & Gender & $\mathrm{N}$ & Mean & Standard Deviation & $\mathrm{F}$ & Sig. & $\mathrm{T}$ & Df & Sig. (2 tailed $)$ \\
\hline \multirow[t]{2}{*}{ Encouragement } & Male & 96 & 3.91 & 0.065 & 0.399 & 0.528 & -1.565 & 242 & 0.119 \\
\hline & Female & 147 & 4.04 & 0.054 & & & & & \\
\hline \multirow[t]{2}{*}{ Planned } & Male & 96 & 3.40 & 0.099 & 3.362 & 0.068 & -0.531 & 242 & 0.529 \\
\hline & Female & 147 & 3.66 & 0.054 & & & & & \\
\hline \multirow[t]{2}{*}{ Surface } & Male & 96 & 3.05 & 0.142 & 0.316 & 0.575 & 1.529 & 242 & 0.128 \\
\hline & Female & 147 & 2.78 & 0.110 & & & & & \\
\hline \multirow[t]{2}{*}{ Deep } & Male & 96 & 3.60 & 0.070 & 1.314 & 0.253 & $-2,216$ & 242 & 0.028 \\
\hline & Female & 147 & 3.79 & 0.049 & & & & & \\
\hline \multirow[t]{2}{*}{ Persistent efforts } & Male & 96 & 3.96 & 0.057 & 0.451 & 0.503 & -1.940 & 242 & 0.054 \\
\hline & Female & 147 & 4.10 & 0.042 & & & & & \\
\hline \multirow[t]{2}{*}{ Total } & Male & 96 & 3.62 & 0.619 & 0.507 & 0.477 & -0.638 & 242 & 0.524 \\
\hline & Female & 147 & 3.67 & 0.566 & & & & & \\
\hline
\end{tabular}

Table 3 shows that there was no significant difference in learning styles among students in the subjects of history by gender, the null hypothesis is rejected fail. However, based on the findings it shows that there is a style of learning styles that have significant differences based on gender, namely deep learning style. There were no significant differences in learning styles surface, deep and persistent effort by gender. The results of this study are also consistent with a study conducted by Tan Lay Guat. (2006). [17], which showed no significant difference between students' learning styles by gender. Chua Long Chee. (2002) [18] conducted a research on learning styles among male trainees and teacher trainers women found no significant difference except for organized learning style.

However, these findings contradict the findings Rahayu Bin Johari (2008) [19] in his study found that there is a significant difference between encouragement learning style male and female students. The study found that girls are more likely to practice learning styles encouragement than boys. This study in contrast to a study conducted by Nor Aniza Ahmad (2011) [27] confirming that there is a significant difference between learning styles and gender. 
Based on the findings, showed that deep learning style has a significant difference, the mean scores showed that female students are more likely to practice deep learning style than male students. Deep learning style refers to curiosity-depth knowledge they have learned. Students who tend to practice this learning style have a strong interest to deepen the content of the lessons. This shows that the girls are seen to have a strong interest in understanding the subjects of history than males. These findings are also supported by a study conducted by Watkins and Katie in his study of university students using 'Study Behavior Questionnaire' (SBQ) and the Biggs' Leaning Process Inventory of Schmeck'. The findings of research showed that female students showed a high interest and depth to the subject of study than male students. In addition, they are learning how to be more manageable than male students.

Most students have the impression that the subject of history is a boring subject, unattractive, useless and meaningless to them (Kaya Yilmaz., 2009) [28].This initial response would cause the students less focused and less motivated to learn the subjects of history, especially the boys. The statement in line with the findings of this study showed that many students are not interested in especially male subject's history and they are more likely to adopt surface learning styles. Watkins \& Katie (1981) reported that male students are more likely to adopt pragmatic learning styles that have a high concern for their assignments and they just want to pass only the examination.

According to Sharifah (2000), students in the country are consisting of multiple backgrounds, races, religions, and cultures. This learning style differences may be caused by such factors. To overcome this problem, teachers must know to analyze or assess learning styles tend to be practiced by the students to the teaching style of teachers in line with students' learning styles. This will attract students to explore subjects studied. Oxford R.L. et al (1991) [14] states that posits social orientation, verbal skills, and with normal strength and strong academic linguistics among girls was partly responsible for the differences between the learning styles of boys and girls.

In addition, teaching factors also affect learning styles to explore one of these subjects. The statement in line with the views (Ong Sze Chong \& Zamri Mahamod, 2014) [25] states that female teachers often have a positive role model or role model to women, but not subject to the boys . For girls, they have the motivation level of selfmotivation, family, and teachers, perseverance and responsibility that exists in female students than male students. Thus, overall found that there are differences in learning styles tend to bias practiced by boys and girls.

D. Relationship between Learning Styles with Performance

\begin{tabular}{cccc} 
Table 4: Relationship between Learning Styles with Performance. \\
\cline { 2 - 4 } Relationship & \multicolumn{2}{c}{ Achievement } & Interpretation \\
\cline { 2 - 3 } Learning Styles & $\mathrm{r}$ & Sig. & \\
\hline & & & \\
Encouragement & 0.151 & 0.051 & - \\
Planned & 0.013 & 0.844 & - \\
Surface & $-0.136^{*}$ & 0.033 & Low \\
Deep & -0.001 & 0.988 & - \\
Persistent efforts & $0.130^{*}$ & 0.042 & Low \\
& & & \\
\hline Total & -0.016 & 0.806 & - \\
\hline
\end{tabular}

Table 4 shows that there is no significant relationship between learning styles and achievement of students in the subjects of history, the null hypothesis is rejected fail. However, there are two styles that have a significant relationship with achievement of learning styles and learning styles of hard work, but it has a small correlation power of interpretation.

The findings are in line with Mohamed Zakaria. (2007) [26], (Kaya Yilmaz., 2009) [28], and Abd. Aziz Ismail. (2001)[30], where there is no significant relationship between learning styles and student achievement. Sabri Ahmad.( 2007) [31] in his study of the control group and the treatment group found also that there was no significant difference between learning styles and student achievement in both groups, namely pre and post group. He also concluded that the uses of force are not appropriate learning helps students to get academic excellence. However, this study contradict a study conducted by Rohazal found that there is a significant relationship between learning styles and achievement in the sixth form mathematics. Kunday is Labeh (2005) [32] study, and Suresh Kumar A/L Kesavelu. (2005) [33] also found that there was a significant relationship between learning styles and student achievement. Although the findings by the researchers is not comparable to a study conducted by them. However, by adopting a learning style that suits a person it will give students' academic excellence to students.

According to Gracia, F.C. \& Hughes, E. H. (2000) [34], students who have excellent academic achievements often have learning styles that are appropriate to themselves, while for students with low 
academic achievement as well as not have the learning style that suits them and not have a goal and planning while studying. Students are unable to find and adopt a learning style that suits them. According Hasmah Binti Iberahin (2014) [5] and Bahrin Abu (2000) [6] the cause of the deterioration of student academic is that they cannot adjust their teaching style to the style of teaching that is done by the teacher and does not have the right learning style.

Academic excellence of students also assisted by wise teachers adjusts their teaching styles and learning styles of students. This resulted in students not having the pressure and the onset of fun while learning and can attract students to explore subjects studied thus gained outstanding achievements in academic. Failure to adjust the teacher in the learning style of students during the learning process led to not pay attention and focus on the teacher. Its effects, students will be left behind in these subjects and encouraged them to fail the exam. The statement was supported by Pask, G. (1988) [35] stated that student achievement has to do with style of teaching disclosed by teachers. Students are taught in a style appropriate to the learning styles that students get satisfaction while studying and getting good results.

\section{CONCLUSION}

Aspects of learning styles are one thing that is important to the students and have to be prioritized by all teachers in the learning process in the classroom. Although in this study the learning styles of students do not have relationships with students' achievement, but the use of the learning styles which corresponds to the learning style of the individual often will acquire outstanding achievement in academics. Advantages and disadvantages of learning styles can help students to improve their weaknesses in the learning process. Learning styles play an important role in the learning process because the learning process will last a lifetime. Therefore, teachers also need to be creative in analyzing and adjusting their teaching styles to student learning styles. Teachers need to be smart to plan and organize activities that can provide pleasure and deepen students' interest in the subject they are studying. It can give students learn with pleasure, so to help them get good results in examinations.

\section{REFERENCES}

[1] Anuar Ahmad, Siti Haishah Abd Rahman \& Nur Atiqah T. Abdullah. (2009). Tahap Keupayaan Pengajaran Guru Sejarah dan Hubungannya dengan Pencapaian Murid Di Sekolah Berprestasi Rendah. Jurnal Pendidikan 34 (1):53-66.

[2] Abdul Razak Ahmad \& Abdullah Mohd Noor. 2000. Kepelbagaian Gaya Pembelajaran Pelajar Dan Pencapaian Akademik. Prosiding Seminar Pendidikan Kebangsaan 2000 :1-12.

[3] Zubaidah Begam. 2007. Hubungan Gaya Pembelajaran Dengan Pencapaian Akademik : Tinjauan Di Kalangan Pelajar Pelajar Sarjana Muda Pendidikan Tahun 1, UTM, Skudai, Johor. Latihan Ilmiah Sarjana. Skudai : UTM

[4] Rosita Binti Ishak. 2012. Gaya Pembelajaran Pelajar Bagi Mata Pelajaran Autocad dan Hubungan dengan Pencapaian Pelajar UNIKL MFI. Latihan Ilmiah Sarjana. Bangi: UKM.

[5] Hasmah Binti Iberahin. 2014. Pengaruh Faktor Persekitaran Terhadap Kecermerlangan Akademik Pelajar Fakulti Kejuruteraan Mekanikal dan Pembuatan Serta Pelajar Fakulti Kejuruteraan Elektrik di UTHM. Latihan Ilmiah Sarjana. Johor : UTHM.

[6] Bahrin Abu. 2000. Teaching Effectiveness and Staff Professional Development Programmes in HEL in Malaysia. Latihan Ilmiah PhD. UK :The University of Birmingham.

[7] Mohd. Mahzan Awang, Abdul Razaq Ahmad, Alfitri, Norila La Ulu. (2014). The Images of Japanese Army in Malaysian and Indonesian History Textbooks. Journal of Language and Literature, 5 (4) 37-45

[8] Awang Abdullah. 2011. Profil Kajian Kecerdasan Pelbagai dan Gaya Pembelajaran Pelajar Dalam Kalangan Pelajar Tingkatan Enam. Latihan Ilmiah Sarjana. Bangi : UKM.

[9] Selmes, L.P. 1987. Improving Stdy Skill (Charging Perspective in Education). Great Britain: Hodder and Staughton Ltd.

[10] Noorhasliza Binti Mohd Nordin. 2015. Ransangan dan Gaya Pembelajaran Sejarah Pelajar Cemerlang. Latihan Ilmiah Sarjana. Bangi : UKM.

[11] Orhun, N. 2007. An Investigation Into The Mathematics Achievement and Attitude Toward Mathematics With Respect Toleaning Style According To Gender. Internasional Journal of Mathematics Esucation In Science And Techology. 38, 321- 333.

[12] Baharom Mohammad \& Ilyas Hashim. 2010. Gaya Pengajaran dan Pembelajaran. Kuala Lumpur: PTS Profesional.

[13] Dunn, R. 1980. Learning : A Matter of Style. Educational Leardership, 37 : 360.

Domino G. 1970. Interactive effect of an achiement orientation and teaching style on academic achievement. An Reasearch Report.

[14] Oxford R.L. \& Ehman, M.E., dan Lavine, R. 1991. Stylewars Teacher-Student Style $\quad$ Conflict In The Language Classromm. Foreign Language Journal. 28 (1) : 22-31 
[15] Battroff, S.M. 1993. The Impact of Group Versus Individualized Classroom Activities on The Levels of Achievement of Student. In a Tenth-Grade Religion Corse (Group Activities Individualized Activities, Learning Style). Dissertation absctract EDD, La Siera University.

[16] Robiah Sidin. 2000. Kualiti Pengajaran dan Pembelajaran Universiti Tempatan. Jurnal Akademik. 57(7) : $25-40$.

[17] Tan Lay Guat. 2006. Hubungan Antara Gaya Pembelajaran Dengan Sikap Pelajar Tingkatan Empat Terhadap Mata Pelajaran Kimia. Latihan Ilmiah Sarjana. Bangi: UKM.

[18] Chua Long Chee. 2002. Gaya Pembelajaran dan Hubungan dengan Pencapaian Akademik Guru-Guru Pelatih Semester Tiga Maktab Perguruan Sarawak, Miri. Kertas Projek Sarjana. Bangi : UKM.

[19] Rahayu Bin Johari. 2008. Pengaruh Gaya Pengajaran Guru Cemerlang Fizik Terhadap Gaya Pembelajaran dan Pencapaian Dalam Mata Pelajaran Fizik Pelajar Tingkatan 4. Latihan Ilmiah Sarjana. Bangi : UKM.

[20] Ang Foo Mei. 2006. Hubungan Antara Gaya Pembelajaran dengan Pencapaian Mata Pelajaran Fizik Tingkatan Empat Di Daerah Muar, Johor. Latihan Ilmiah Sarjana. Bangi : UKM.

[21] Lee, J.K. 2002. Digital History in The History/Social Studies Classroom. The History Teacher. 43(4), 503-518.

[22] Yi Chien Lu. 2007. ESL Student's Learning Motivasions and Learning Strategies. Disetasion PhD. South Dakota: The University of South Dakota.

[23] Lee Sui Chin. 2003. Perhubungan Terhadap Kimia dan Pengetahuan Aras Sains dengan Pencapaian Pelajar dalam Mata Pelajaran Kimia. Latihan Ilmiah Sarjana Muda. Bangi : UKM.

[24] Jamil Bin Ahmad. 2002. Pemupukan Budaya Penyelidikan di Kalangan Guru Sekolah : Satu Penilaian. Latihan Ilmiah PhD. Bangi : UKM.

[25] Ong Sze Chong dan Zamri Mahamod. 2014. Gaya Pembelajaran Pelajar Bahasa Melayu Berdasarkan Gaya Pembelajaran Grasha. Journal of Applied Research in Education. Vol 18 :52-66.

[26] Mohamed Zakaria. 2007. Hubungan Gaya Pembelajaran Dengan Pencapaian Akademik : Tinjauan Di Kalangan Pelajar-pelajar Sarjana Muda Pendidikan Tahun Pertam. Latihan Ilmiah Sarjana. Skudai : UTM.

[27] Nor Aniza Ahmad. 2011. Gaya dan Strategi Pembelajaran Serta Hubungan dengan Pencapaian Akademik Mengikut Gender dan Jenis Sekolah. Latihan Ilmiah PhD. Bangi: UKM.

[28] Kaya Yilmaz. 2009. A Vision of History Teaching and learning : Thought On History Education In Secondary School. The High School Journal :2-23.

[29] Chua Yah Piaw. 2006. Kaedah penyelidikan. Buku 2. Kuala Lumpur : McGraw Hill.

[30] Abd. Aziz Ismail. 2001. Kajian Gaya Pembelajaran Pelajar Dengan Pencapaian Subjek Geografi Di Sekolah-Sekolah Menengah. Latihan Ilmiah Sarjana. Bangi : UKM.

[31] Sabri Ahmad. 2007. Kesan Strategi Pengajaran Ke Atas Gaya Pembelajaran, Sikap, dan Pencapaian Dalam Matematik. Latihan Ilmiah PhD. Bangi : UKM.

[32] Kundayis Labeh. 2005. Hubungan Antara Stail Pembelajaran Dengan Pencapaian Akademik dan Motivasi Pecapaian Di Kalangan Pelajar Maktab Perguruan Kenangau Sabah. Latihan Ilmiah Sarjana. Bangi : UKM.

[33] Suresh Kumar A/L Kesavelu. 2005. Hubungan Di Antara Gaya Pembelajaran Dengan Pencapaian Akademik Pelajar Sarjana Muda Teknologi Serta Pendidikan Di UTM Dalam Mata Pelajaran Teknologi Pengeluaran Asas. Latihan Ilmiah Sarjana. Skudai : UTM.

[34] Gracia, F.C. \& Hughes, E. H. 2000. Laerning And Thinking Styles : An Analysis Of Their Interrelationship and Influence On Academic Achievement. Educational Psychology. 32(1) : 5-22.

[35] Pask, G. 1988. Styles And Strategies Of Learning. British Journal of Educational Psychology 46 : 128-148. 